\title{
Characteristics and risk factors of snoring and the prevalence of suspected obstructive sleep apnea in children
}

\author{
Bambang Supriyatno, MD; Rusmala Deviani, MD; Alan R Tumbelaka, MD; \\ Evita KB Ifran, MD; Nastiti N Rahajoe, MD
}

\begin{abstract}
Background Snoring as a consequence of upper airway obstruction is common in children. Snoring can be considered as normal, but might also reflect a disease such as obstructive sleep apnea (OSA), which is associated with serious morbidities. In Indonesia, data on the characteristics and risk factors of snoring and obstructive sleep apnea is limited

Objectives The aims of this study were to find out the characteristics and risk factors of snoring in children and to determine the prevalence of suspected OSA in snoring children.

Methods A cross-sectional study was carried out on children aged 5-13 years using parental questionnaires scored according to the Brouilette formula. All children underwent physical examination for weight, height and tonsil size. Adenoid radiology was performed on part of the samples.

Results Of the 917 questionnaires distributed, only 658 were completed. The ratio of boys to girls was equal. Obesity was detected in $18.3 \%$ of children, among whom $54.2 \%$ snored. Obese children were 2.1 times more likely to snore. Besides obesity, rhinitis and atopy were found to be associated with snoring $(\mathrm{PR}=, 95 \% \mathrm{Cl}$; and $\mathrm{PR}=, 95 \% \mathrm{Cl}$; respectively). Asthma and tonsil hypertrophy were shown not to be predisposing factors of snoring. Children with adenoid hypertrophy were 1.8 times more likely to snore habitually. The prevalence of snoring and suspected OSA in children aged $5-13$ years were $31.6 \%$ and $5.9 \%$, respectively.

Conclusion Risk factors of snoring were obesity, adenoid hypertrophy, atopy and rhinitis. Prevalence of snoring in children age 513 years was $31.6 \%$ and that of suspected OSA cases was $5.9 \%$. [Paediatr Indones 2005;45:40-45].
\end{abstract}

Keywords: snoring, obstructive sleep apnea, risk factors, prevalence

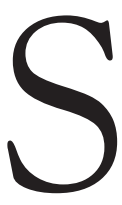

noring is common in children and mostly thought of as normal. ${ }^{1}$ Known predisposing factors of snoring include adenoid hypertrophy and obesity. ${ }^{2}$ Other factors which obstruct the upper airway, such as macroglossia, rhinitis, asthma, atopy, craniofacial abnormalities, and neuromuscular disorders, may lead to snoring. ${ }^{3}$ Frequent upper airway obstruction can influence the physiology of breathing, causing obstructive sleep apnea (OSA). Habitual snoring, or snoring during sleep which occurs almost every night, reflects the presence of OSA.4,5 Obstructive sleep apnea syndrome (OSAS) is characterized by noisy, difficult breathing during sleep and daytime symptoms such as hypersomnolence and excessive daytime sleepiness. ${ }^{6}$ OSA can lead to behavioral problems, learning and attention problems, failure to thrive, hypertension, and cardiovascular complications. ${ }^{7,8}$ The prevalence of habitual snoring varies between $3.2-12 \% .{ }^{9}$ It is difficult to distinguish primary snoring (snoring without hypoxemia, hypercarbia and sleep disturbance) with OSA.

From the Department of Child Health, Medical School, University of Indonesia, Jakarta, Indonesia.

Reprint requests to: Bambang Supriyatno, MD, Department of Child Health, Medical School, University of Indonesia, Cipto Mangunkusumo Hospital, Jakarta, Indonesia. Tel. 62-21-3147342, Fax. 62-21-3148931. 
Bambang Supriyatno et al: Snoring and suspected obstructive sleep apnea in children

Polysomnography examination is necessary to confirm the presence of OSA, but it is expensive and requires overnight stay. ${ }^{6}$ Brouilette formulated a questionnaire to screen OSA, and in which snoring is one of the items ${ }^{10}$. The aim of our study is to find out the characteristics and risk factors of snoring and to determine the prevalence of suspected OSA based on the Brouilette questionnaire.

\section{Methods}

This cross-sectional study was conducted at Al Ikhlas Elementary School in South Jakarta from December 2003 to February 2004. The study protocol was approved by the regional committee on ethics in medical research. We studied the entire population of school children (age 5-13 years), consisting of 917 subjects. An explanatory letter was given to and informed consent obtained from subjects' parents. Inclusion criteria were parental consent, age of 5 to 13 years old, being registered at Al Ikhlas Elementary School, and having no neuromuscular or craniofacial abnormality. Parents of subjects were asked to observe their child while sleeping for one week, at least two hours a day, and subsequently answer a questionnaire. The questionnaire was formulated according to the Brouilette guidelines, as revised by Basic Nordic Sleep Questionnaires. ${ }^{11}$ The questionnaire predicted OSA based on a formula incorporating three variables, which were breathing difficulty during sleep, apnea and snoring. Items in the questionnaire included: (1) Does your child snore at night? (2) Does your child have difficulty in breathing during sleep? (3) Does your child stop breathing at least twice during sleep? If they answered 'yes' on any of these questions, they must choose another answer using the Likert scale (sometimes, often, or always). Each answer was scored accordingly and the final score calculated according to the Brouilette formula. A score of $>3.5$ completely predicted the presence of OSA, <-1 completely predicted the absence of OSA, and a score between -1 and 3.5 was indeterminate (suspected, but could not be confirmed).

Habitual snoring (HS) was established if the answer was 'often' or 'always', and occasional snoring (OS) when the answer was 'often' or 'sometimes'. Children were classified as asthmatic if this was declared by a doctor. Atopy was defined as having experienced an allergy. A child was said to suffer from rhinitis if he/she had experienced a runny nose without fever for 2 weeks. Interpretation of adenoid radiology was performed by pediatric radiologists and the authors. Inter-observer variability was assessed using the Cohen and Konak methods. ${ }^{12}$

All subjects underwent physical examination for weight, height and tonsil size. Body mass index (BMI) for age and sex were classified according to $\mathrm{CDC}^{13}$ as obese $\left(=\mathrm{P}_{95}\right)$, overweight $\left(=\mathrm{P}_{85}\right.$ and $\left.<\mathrm{P}_{95}\right)$, well-nourished $\left(=\mathrm{P}_{5 \text { and }}<\mathrm{P}_{85}\right)$, or undernourished $\left(<\mathrm{P}_{5}\right)$. Tonsil hypertrophy was defined as tonsil size of $\mathrm{T}_{2}-\mathrm{T}_{3}$.

The prevalence of snoring and suspected obstructive sleep apnea, respectively, were calculated. The prevalence ratio and 95\% confidence intervals of snoring was determined for the following factors: BMI, asthma, rhinitis, atopy, and adenotonsilar hypertrophy. SPSS 11.0 was used to aid in the analysis.

\section{Results}

Of the 917 questionnaires, 667 were returned, representing an overall response rate of $72.7 \%$. Nine respondents refused to participate in this study, leaving only 658 subjects, 305 (46.4\%) male and 353 (53.6\%) female, to be analyzed. Subject characteristics can be viewed in Table 1 .

Snoring was found in 208 (31.6\%) children (OS $26.4 \%$; HS 5.2\%). Snoring was more common in children aged 5-7 years, with a male to female ratio of 1.1:1. Obesity was found in 120 (18.3\%) children, overweight in $84(12.7 \%)$, good nutrition in 378 $(57.4 \%)$, and undernutrition in $76(11.6 \%)$. Obesity was detected in 49/174 (28.5\%) and 16/34 (47.1\%) children with OS and HS, respectively. The clinical profile of snoring children is shown in Table 2.

In order to investigate the risk factors of snoring, we compared snorers and non-snorers. Table 3 shows that children with obesity, rhinitis and atopy were $2.1(95 \% \mathrm{CI}, 1.7 ; 2.6), 1.4(95 \% \mathrm{CI}, 0.9 ; 1.9)$ and $1.5(95 \% \mathrm{CI}, 1.1 ; 1.7)$ times more likely to snore, respectively. The prevalence ratio of snoring in children with asthma and tonsilar hypertrophy and the association between these two factors with snoring were not significant.

Based on radiography, 30/88 snoring children had adenoid hypertrophy. Of these, 16 were habitual snorers. The prevalence ratio of snoring in 
Table 1. Subject characteristics

\begin{tabular}{|c|c|c|c|c|}
\hline \multirow[t]{2}{*}{ Snorers } & \multicolumn{3}{|c|}{ Non-snorers } & \multirow[b]{2}{*}{$\%$} \\
\hline & $\mathbf{n}$ & $\%$ & $\mathbf{n}$ & \\
\hline \multicolumn{5}{|l|}{ Sex } \\
\hline Male & 114 & 17.3 & 191 & 29.1 \\
\hline Female & 94 & 14.3 & 259 & 39.3 \\
\hline \multicolumn{5}{|l|}{ Age } \\
\hline $5-7$ years & 93 & 14.0 & 126 & 19.2 \\
\hline $8-10$ years & 56 & 8.6 & 135 & 20.5 \\
\hline $11-13$ years & 59 & 9.0 & 189 & 28.7 \\
\hline \multicolumn{5}{|l|}{ BMI } \\
\hline $\mathrm{BMI}=\mathrm{P}_{95}{ }^{\text {th }}$ & 65 & 10.0 & 55 & 8.3 \\
\hline $\mathrm{P}_{85}{ }^{\text {th }}=\mathrm{BMI}<\mathrm{P}_{95}{ }^{\text {th }}$ & 30 & 4.5 & 54 & 8.2 \\
\hline $\mathrm{P}_{5}^{\text {th }}=\mathrm{BMI}<\mathrm{P}_{85}^{\text {th }}$ & 100 & 14.8 & 278 & 42.6 \\
\hline $\mathrm{BMl}<\mathrm{P}_{5}^{\text {th }}$ & 13 & 2.0 & 63 & 9.6 \\
\hline \multicolumn{5}{|l|}{ Tonsil size* } \\
\hline $\mathrm{T}_{3}$ & 49 & 9.4 & 76 & 14.5 \\
\hline $\mathrm{T}_{2}^{3}$ & 64 & 12.2 & 143 & 27.4 \\
\hline $\mathrm{T}_{1}^{2}$ & 39 & 7.4 & 125 & 23.9 \\
\hline $\mathrm{T}_{0}^{\prime}$ & 9 & 1.7 & 18 & 3.4 \\
\hline
\end{tabular}

*) 135 children were not examined for tonsil size

Table 2. Clinical PROfile of snoring Children

\begin{tabular}{|c|c|c|c|c|}
\hline \multirow[t]{2}{*}{ Variable } & \multicolumn{2}{|c|}{ Occasional snorers } & \multicolumn{2}{|c|}{ Habitual snorers } \\
\hline & $\mathbf{n}$ & $\%$ & $\mathbf{n}$ & $\%$ \\
\hline \multicolumn{5}{|l|}{$\overline{\text { Sex }}$} \\
\hline male & 90 & 13.7 & 24 & 3.6 \\
\hline Female & 84 & 12.8 & 10 & 1.5 \\
\hline \multicolumn{5}{|l|}{ Age } \\
\hline $5-7$ years & 76 & 11.5 & 17 & 2.5 \\
\hline 8 - 10 years & 45 & 6.8 & 11 & 1.8 \\
\hline $11-13$ years & 53 & 8.1 & 6 & 0.9 \\
\hline \multicolumn{5}{|l|}{ BMI } \\
\hline $\mathrm{BMI}>\mathrm{P}_{95}^{\text {th }}$ & 49 & 7.5 & 16 & 2.5 \\
\hline $\mathrm{P}_{85}^{\text {th }}=\mathrm{BMl}<\mathrm{P}_{95}^{\text {th }}$ & 26 & 3.9 & 4 & 0.6 \\
\hline $\mathrm{P}_{5}^{85}<\mathrm{BMl}<\mathrm{P}_{85^{\text {th }}}^{95}$ & 88 & 13.2 & 12 & 1.6 \\
\hline $\mathrm{BMl}<\mathrm{P}_{5}^{\text {th }}$ & 11 & 1.7 & 2 & 0.3 \\
\hline \multicolumn{5}{|l|}{ Tonsil size ${ }^{*}$} \\
\hline$T_{3}$ & 38 & 7.3 & 11 & 2.1 \\
\hline $\mathrm{T}_{2}^{3}$ & 56 & 10.7 & 8 & 1.5 \\
\hline $\mathrm{T}_{1}^{2}$ & 34 & 6.5 & 5 & 0.9 \\
\hline $\mathrm{T}_{0}^{1}$ & 9 & 1.7 & 0 & 0 \\
\hline
\end{tabular}

children with and without habitual snoring was 1.8 (95\%CI, 1.1;3.1). Kappa value between the tinterpretations of pediatric radiologists and the authors was 0.7.

Based on the Brouilette formula, 39/658 (5.9\%) subjects scored between -1 and 3.5, indicating suspected, although not confirmed, OSA. Suspected OSA was found in 28/174 (16.1\%) and $11 / 34$ subjects with OS and HS, respectively. Apnea symptoms were found in $8 / 39$ children and difficulty in breathing during sleep in all children with suspected OSA.

\section{Discussion}

This study showed that the prevalences of OS and HS were $26.4 \%$ and $5.2 \%$, respectively. These results are similar to that of Ferreira et $\mathrm{al}^{14}$ (OS 30.6\%; HS 8.6\%) and Anuntaseree ${ }^{15}$ (OS 24.7\%; HS $8.5 \%$ ), which were population-based studies on children aged 6-13 years. Corbo et al ${ }^{16}$ and Gislason et al $^{17}$ reported lower results (OS 8.5\%; HS 7.3\% and OS $16.7 \%$; HS 3.2\%) but they used different criteria for snoring and investigated a younger population. 
Bambang Supriyatno et al: Snoring and suspected obstructive sleep apnea in children

Table 3. Prevalence ratio of SNoring in Children With and Without obesity, asthma, RHinitis, ATOPY, AND TONSILLAR HYPERTROPHY

\begin{tabular}{|c|c|c|c|}
\hline \multirow[t]{2}{*}{$\overline{\text { Variable }}$} & \multirow[t]{2}{*}{ Snorers } & \multirow[t]{2}{*}{ Non-snorers } & \multirow{2}{*}{$\begin{array}{l}\text { Prevalence ratio } \\
95 \% \mathrm{Cl}\end{array}$} \\
\hline & & & \\
\hline \multicolumn{4}{|l|}{ Obesity } \\
\hline Yes & 65 & 55 & 2.1 \\
\hline No & 140 & 396 & $1.7 ; 2.6$ \\
\hline \multicolumn{4}{|l|}{ Ashtma } \\
\hline Yes & 37 & 43 & 1.1 \\
\hline No & 171 & 407 & $0.9 ; 1.9$ \\
\hline \multicolumn{4}{|l|}{ Rhinitis } \\
\hline Yes & 63 & 88 & 1.4 \\
\hline No & 145 & 362 & $1.1 ; 1.7$ \\
\hline \multicolumn{4}{|l|}{ Atopy } \\
\hline Yes & 64 & 97 & 1.5 \\
\hline No & 144 & 353 & $1.2 ; 1.9$ \\
\hline \multicolumn{4}{|c|}{ Tonsilar hypertrophy } \\
\hline Yes & 133 & 219 & 1,4 \\
\hline No & 48 & 143 & $1.0 ; 1.8$ \\
\hline
\end{tabular}

In this study, the prevalence of snoring was equal in boys and girls, whereas in the adult population, it is predominant in men $(6: 1) .{ }^{18}$ The percentage of male children with HS was higher than that of female children $(3.6 \%$ vs $1.5 \%)$. Until now, the exact mechanism of the male predominance in snoring is still unknown. Some experts have suggested that a higher resistance of the pharynx-supraglottis and upper airway may be the culprit. ${ }^{19}$

Table 1 shows that snoring is more common in children between the age of 5-7 years. This result was similar to that of Ali et all ${ }^{20}$ and Teculescu et al. ${ }^{21}$ In the age of 3-6 years, redundant growth of the adenoid and tonsil plays a major part in the enlargement of the nasopharyngeal soft tissues, leading to narrowing of the nasopharyngeal area. In this study, $113(21.6 \%)$ children with tonsillar hypertrophy snored (OS 94/208; HS 19/34), but statistically there was no significant association. This result was supported by the fact that there were children who snored even without tonsilar hypertrophy. Nieminen et al${ }^{22}$ reported similar results. Based on radiological findings, children with adenoid hypertrophy were 1.8 times more likely to have HS, and 10/32 children with adenoid hypertrophy were suspected of OSA in this study. Chay ${ }^{23}$ found that children with OSA have 7 and 4 times higher probabilities of tonsilar and adenoid hypertrophy, respectively.

Obesity is believed to be a predisposing factor for snoring and OSA because of mass loading of the upper airway muscle and soft tissue by adipose tissue in the neck, which leads to adenoid enlargement. ${ }^{24}$ This study showed that obese children were 2.1 times more likely to snore. Marcus et al, ${ }^{25}$ Corbo et $\mathrm{al}^{3}$ and Teculescu et a ${ }^{11}$ reported similar results. In this study 13/39 children with suspected OSA were obese. Marcus et al ${ }^{25}$ found a correlation between OSA and obesity. On the other hand, David and Stradling ${ }^{26}$ found that neck circumference, rather than obesity, correlated more strongly with OSA. It is not clear why obese people develop OSA. Adipose tissue surrounding the airway and external trunk reduces thoracic cage compliance, causes mass loading of the respiratory muscles and increases pharyngeal resistance. ${ }^{27}$

This study found that children with rhinitis and atopy were more likely to snore, but asthma and tonsil hypertrophy statistically were not shown as predisposing factors. Corbo et al ${ }^{8}$ reported similar results, although $\mathrm{Lu}$ et $\mathrm{al}^{28}$ and Teculescu et al ${ }^{18}$ found different results. Lu and Teculescu used logistic regression to analyze the variable, which was not employed in this study.

Apnea occurred in 8/39 children, whereas difficulty in breathing was found in all children with suspected OSA. All children with suspected OSA in this study had Brouilette score between -1 and 3.5, which required polysomnography to confirm the diagnosis of OSA. Unfortunately, due to financial limitations, it could not be performed in this study. Although the Brouilette questionnaire was not the gold standard 
for diagnosing OSA, this tool was used because of its sensitivity and specificity of 73 and $83 \%$, respectively.

In conclusion, the prevalence of snoring in children aged $5-13$ years is $31.6 \%$ (OS 26.4\%; HS 5.2\%). Obesity, adenoid hypertrophy, rhinitis, and atopy are risk factors for snoring. The prevalence of suspected OSA according to the Brouilette questionnaire is $5.9 \%$. In further studies, we recommend that polysomnography be performed to confirm the presence of OSA.

\section{References}

1. Kiely JL, McNicholas WT. Overview and historical aspects of breathing disorders during sleep. In: McNicholas WT, editor. Respiratory disorders during sleep. London: European Respiratory Society Journals Ltd; 1998. p. 1-8.

2. Bar A, Tarasiuk A, Segar Y, Phillip M, Tal A. The effect of adenotonsilectomy on serum insulin like growth factor-I and growth in children with obstructive sleep apnea syndrome. J Pediatr 1999;135:76-80.

3. Corbo GM, Forastiere FF, Agabiti N, Istelli R, Dell'Arco V, Peruci CA. Snoring in 9- to 15-year-old children: risk factors and clinical relevance. Am Acad Pediatr 2001;108:1149-53.

4. Redline S, Tishler PV, Schluchter M, Aylor J, Clark K, Graham G. Risk factors for sleep disordered breathing in children. Associations with obesity, race and respiratory problems. Am J Respir Crit Care Med 1999;159:1527-32.

5. Kasey K, Nelson B, Kushida C, Riley R, Adorneto B, Guileminaut C. A comparison of Asian and white patients with OSA syndrome. Laryngoscope 1999;109:1937-40.

6. Caroll JL, Mc Colley SA, Marcus CL, Curtis S, Loughlin GM. Inability of clinical history to distinguish primary snoring from obstructive sleep apnea syndrome in children. Chest 1995;108:610-8.

7. Guilleminault C, Tilkian A, Demant W. The sleep apnea syndromes. Citated by Dyson MC, Beckerman RC. Obstructive sleep apnea syndrome. In: Hilman $\mathrm{BC}$, editor. Pediatric respiratory disease diagnosis and treatment. Lousiana: WB Saunders Company; 1993. p. 563-73.

8. Marcus C, Hamer A, Loughin GM. Natural history of primary snoring in children. Pediatr Pulmonol 1998;26:6-11.
9. Schechter MS. Technical report: Diagnosis and management of childhood obstructive sleep apnea syndrome. Pediatr 2002;109:1-20.

10. Brouillette R, Hanson D, David R. A diagnostic approach to suspected obstructive sleep apnea in children. J Pediatr 1984;105:10-4.

11. Teculescu D, Hanhart B, Aubry C. Who are the occasional snorers? Am College of Chest Phys 2002;122.

12. Cohen D, Konak S. The evaluation of radiographs of the nasopharynx. [abstract] Clin Otolaryngol 1985;10:73-8.

13. National Center for Chronic Disease Prevention and Health Promotion. BMI for children and teens. Avaiable at: URL: http://www.cdc.gov/hccdphp/dnpa/ bmi/bmi-for-age.htm

14. Ferreira AM, Clemente V, Gozal D, Gomes A, Pissarra C, Cesar H, et al. Snoring in Portuguese primary school children. Pediatrics 2000;106.

15. Anuntaseree W, Rookkapan K, Kuasirikuit S, Thongsuksai P. Snoring and obstructive sleep apnea in Thai school-age children: prevalence and predisposing factors. Pediatr Pulmonol 2001;32:222-7.

16. Corbo GM, Fuciarelli F, Foress A, Benedetto F. Snoring in children: association with respiratory symptoms and passive smoking. Br Med J 1989;299:1491-4.

17. Gislason T, Benediktsdottir B. Snoring, apneic episodes and nocturnal hypoxemia among childern 6 months to 6 years old. An epidemiologic study of lower limit of prevalence. Chest 1995;107:963-66.

18. Young T, Peppard PE, Gottlieb DJ. Epidemiology of obstructive sleep apnea. A population health perspective. Am J Respir Crit Care Med 2002;165:1217-38.

19. Deegan PC, McNicholas WT. Pathophysiology of obstructive sleep apnoea. In: McNicholas WT, editor. Respiratory disorders during sleep. London: European Respiratory Society Journals Ltd; 1998. p. 28-62.

20. Ali NJ, Pitson DJ, Stradling JR. Snoring, sleep disturbance \& behavior in 4 - 5 year olds. Arch Dis Child 1993; 68:360-6.

21. Teculescu DB, Caillier I,Perin P, Rbestock E, Rauch A. Snoring in French preschool children. Pediatr Pulmonol 1992;13:239-244.

22. Nieminen P, Tolonen U, Lopponen H. Snoring and obstructive sleep apnea in children, a 6- month follow-up study. Arch Otolaryngol Head Neck Surg 2000;126:481-6.

23. Chay M, Goh A, Abisheganaden J, Tang J, Lim WH, Chan $\mathrm{YH}$, et al. Obstructive sleep apnea syndrome in obese Singapore children. Pediatr Pulmonol 2000;29:284-90. 
24. Mortimore IL, Marshal I, Waith PK, Sellar RJ, Douglas NJ. Neck and total body fat deposition in non obese and obese patients with sleep apnea compared with that in control subject. Am J Respir Crit Care Med 1998;157:280-3

25. Marcus CL, Curtis S, Koerner CB, Joffe A, Serwint JR, Loughlin GM. Evaluation of pulmonary function and polysomnography in obese children and adolescent. Pediatr Pulmonol 1996; 21:176-83.

26. Davies RJ, Ali NJ, Stradling JR. Neck circumference and other clinical features in the diagnosis of the ob- structive leep apneoea syndrome. [abstract] Thorax 1992;47:101-5.

27. Mallory GB, Fiser DH, Jackson R. Sleep-associated breathing disorders in morbidly obese children and adolescents. J Pediatr 1989;115:892-7.

28. Lu L, Peat J, Sullivan C. The prevalence of snoring in preschool children and its association with night cough and asthma. [abstract] Proceedings of the 6th World Sleep Congress; 2000 Mar 12-15; Sydney, Australia. Sydney: World Sleep Society; 2000. 